GARCIA, Sylvia G. 2002. Destino Ímpar: Sobre a Formação de Florestan Fernandes. São Paulo: Ed. 34. 191 pp.

\section{Heloisa Pontes}

Professora, Unicamp

Homem "sem geração", dono de uma história de vida singular e quase impensável à luz do padrão de sociabilidade das nossas elites intelectuais, o sociólogo Florestan Fernandes ganhou nome, sobrenome e notoriedade a partir da sua atuação na Faculdade de FiIosofia da Universidade de São Paulo. N ascido em São Paulo, em julho de 1920, filho de pai desconhecido e de Maria Fernandes, Florestan descendia de uma família de imigrantes portugueses que vieram para o Brasil "tangidos pela fome". A qui viveram uma "história dramática de desagregação familiar e de duros sacrifícios" (segundo entrevista que Florestan concedeu ao Museu da Imagem e do Som em 1981, publicada, de forma reduzida, em $\mathrm{N}$ ovos Estudos Cebrap, 42). O avô materno, que trabalhara como colono em uma fazenda no interior de São Paulo, morreu tuberculoso e a mãe, após se mudar para a capital paulista, sobrevivia como empregada doméstica.

Ao relembrar a sua condição de "típico morador pobre da cidade de São Paulo na década de 20", Florestan afirma que "o menino que eu era vivia [...] fascinado pelo luxo de uns ou pela pompa dos que desciam de carros com motoristas de libré, abrindo as portas, diante do Teatro M unicipal ou do Cine Paramount; passando o dia-a-dia oscilando entre a fome e a fartura, trabaIhando como se fosse adulto - o código de honra de ninguém evitava esse "fardo de criança" - e tendo de admitir que a limpeza exigente de minha mãe não excluía a presença das baratas, a roupa remendada e larga - ganha de famílias generosas ou herdada dos mais veIhos". (Esta e as demais citações de Florestan foram retiradas de seu artigo "Em Busca de uma Sociologia Crítica e Militante", incluído em A Sociologia no Brasil, 1977.)

A os 9 anos de idade, depois de cursar por três anos o primário, Florestan interrompeu os estudos para trabalhar. E só voltou à escola aos 17 anos, para fazer o curso de madureza no Ginásio Riachuelo, conciliando o dia de trabaIho com os estudos no período noturno. Em suas palavras, “o Riachuelo logo desvendou um mundo novo, em que os professores e as lições não seriam o único eixo. Os estudantes compartilhavam comigo certas dificuldades - não todas. Ninguém possuía origens tão toscas e um desenraizamento tão profundo. Contudo, todos trabalhavam e viam no curso de madureza uma instrumentalidade que eu desconhecia. Todos íamos lá para aprender [...]. Passei, então, do pato ao ganso".

Pela primeira vez, Florestan sentiu que podia romper com a "degradação social tácita" que estava implícita em sua condição. Uma "alegria enorme" e "uma esperança sem limites" somavam-se à descoberta de que podia "viver como gente" e lançar-se "na corrente". A cidade de São Paulo deixara de ser apenas o lugar de "encantos proibidos", convertendo-se em um espaço de possibilidades concretas. Decidido a cursar a universidade, Florestan inscreveu-se no vestibular para a Faculdade de Filosofia da Universidade de São Paulo, onde ingressou aos 21 anos. No começo de 1941, enquanto iniciava o curso de graduação em ciências sociais, os integrantes do "Grupo Clima" preparavam-se para lançar a revista que traria notabilidade a vários de seus edi- 
tores e colaboradores. A Faculdade na qual todos estavam ou estiveram inseridos como alunos completava, por sua vez, o sétimo ano de existência. Sob o signo da juventude, da instituição e de seus membros, saíram a campo, criaram novos projetos de intervenção cultural e implementaram novas formas de trabaIho intelectual.

Florestan escolheu as ciências sociais porque acreditava que essa disciplina coincidia com os seus interesses intelectuais "mais profundos". Mas antes de tudo queria ser professor. Sua opção pelas ciências sociais, motivada por um "vago socialismo" e pelo desejo então impreciso de "mudar a sociedade", passou ao largo da escolha de uma profissão. Ele, que até então se sustentara com empregos variados, ingressou na Faculdade de Filosofia sem se colocar, de início, esse problema. Mesmo porque, no começo do decênio de 40 , ninguém sabia com clareza o que era ser cientista social e muito menos o que se poderia esperar desse tipo de profissão.

Florestan Fernandes era o homem certo para a Faculdade de destino ainda incerto. Sua origem social, somada às dificuldades de toda ordem que enfrentara na infância e na adolescência, dificilmente Ihe franquearia o ingresso em uma Faculdade como a de Direito ou a de Medicina. Destituído de todo tipo de capital, ele encontrou no curso de ciências sociais o espaço possível para romper com o "círculo de ferro" de sua condição social. Criada em um caldo de cultura em que se misturavam o movimento modernista e sua rotinização, a leva de "retratos" do Brasil e novos projetos de política cultural, a Faculdade de Filosofia tornou-se, em pouco tempo, o centro e o eixo em torno do qual girou a formação de um novo sistema acadêmico de produção intelectual. Im- plantado por professores estrangeiros, franceses em particular, esse sistema foi se aclimatando e fincando raízes no campo intelectual paulista, graças à atuação, no decorrer dos decênios de 40 e 50, dos membros mais expressivos do corpo discente da Faculdade de Filosofia: os integrantes do "Grupo Clima" e os cientistas sociais sob a liderança intelectual e institucional de Florestan Fernandes.

Afinados com o que se passava na literatura, no cinema, nas artes plásticas e no teatro, os primeiros fizeram da crítica o elo de ligação entre a tradição intelectual brasileira, fortemente impregnada pelo ensaísmo, e o estilo acadêmico instaurado pela Faculdade. Diferentemente deles, Florestan empenhou-se com obstinação na criação de uma linguagem especializada, pautada pela idéia de cientificidade. Longe de ser apenas uma questão formal, seu estilo de exposição e explicação dos fenômenos sociais tornou-se um dos elementos centrais para a criação da identidade disciplinar da sociologia e de seus praticantes na época. Sinonimizando ensaísmo a amadorismo, Florestan travou uma luta simbólica no plano da linguagem com o propósito de legitimar e consolidar a sociologia. Vitorioso, ele converteu a cadeira de Sociologia I da Faculdade de Filosofia em um dos maiores centros de produção sociológica do país, conhecido por "Escola Paulista de Sociologia".

Não é de estranhar, portanto, que a obra monumental e a trajetória incomum de Florestan venham suscitando novas interpretações por parte de estudiosos do pensamento social brasileiro. Nessa direção, destacam-se os trabaIhos de Mariza Peirano e de Maria Arminda Arruda, e o livro em tela da socióloga Sylvia Garcia. Em seu Destino Ímpar, a autora elabora uma interpreta- 
ção vigorosa do período de formação de Florestan, que se estende dos anos 20 e 30 - correspondentes à experiência doída de menino pobre - até 1953, quando ele defende a tese de livre-docência, conquista a maioridade acadêmica e se projeta como o sociólogo mais talentoso da Faculdade. Muito bem escolhido, o título do livro condensa um duplo feito. Sintetiza o argumento da autora - na sua acertada recusa em dissociar a biografia de Florestan de sua produção intelectual, e ambas do contexto histórico que dá sustentação à estruturação da Faculdade e às transformações sociais e culturais na São Paulo da época - ao mesmo tempo que oferece uma imagem vívida do percurso de Florestan. Í mpar em relação ao destino de seus colegas de profissão, Florestan foi também singular na história da sua família.

Valendo-se basicamente das entrevistas e dos textos autobiográficos que Florestan produziu a partir dos anos 70 , quando já se encontrava fora da Faculdade em razão da sua aposentadoria compulsória pela ditadura militar, Sylvia Garcia não perde de vista o entrelaçamento das dimensões psicológicas e pessoais do sociólogo com as "possibilidades presentes na configuração sóciohistórica da metrópole paulistana e, em especial, em seu campo intelectual e universitário" (:173). Sem cair nas armadilhas fáceis do gênero biográfico, sobretudo diante de alguém como Florestan, cujo período de formação intelectual coincide também com o seu momento de ascensão social, Sylvia arma o contexto narrativo necessário para entendermos a excepcionalidade desse sociólogo. Bem escrito e apaixonado, o livro enreda o leitor nas tramas empolgantes e muitas vezes dilaceradas que deram sentido e consistência à trajetória de Florestan. Vale a pena conferir. 